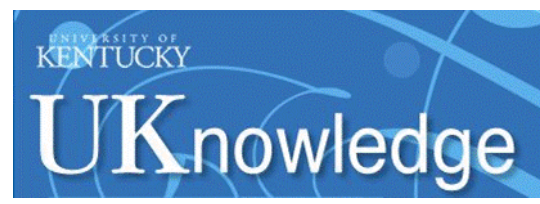

Kentucky Law Journal

Volume 45 | Issue 2

Article 4

1956

\title{
On the Form and Structure of Man's Inner Freedom
}

Erwin W. Straus

Veterans Administration Hospital

Follow this and additional works at: https://uknowledge.uky.edu/klj

Part of the Law and Society Commons

Right click to open a feedback form in a new tab to let us know how this document benefits you.

\section{Recommended Citation}

Straus, Erwin W. (1956) "On the Form and Structure of Man's Inner Freedom," Kentucky Law Journal: Vol. 45: Iss. 2, Article 4.

Available at: https://uknowledge.uky.edu/klj/vol45/iss2/4

This Article is brought to you for free and open access by the Law Journals at UKnowledge. It has been accepted for inclusion in Kentucky Law Journal by an authorized editor of UKnowledge. For more information, please contact UKnowledge@lsv.uky.edu. 


\title{
On the Form and Structure of Man's Inner Freedom*
}

\author{
By ERwin W. Straus, M.D.**
}

\begin{abstract}
$\mathrm{H}$
ISTORY, the scene of human choice and action, opens with the expulsion from Paradise. It began, according to the Bible, with an event of man's own making, a rebellious deed, creating a situation from which there was no retreat to the past. In his disobedience Adam gambled for the highest price: to be like God. "In the day ye eat thereof," the serpent promised, "then your eyes shall be opened, and ye shall be as gods, knowing good and evil." Here the serpent did not lie. The Lord confirmed his words: "Behold, the man is to become as one of us, to know good and evil."
\end{abstract}

In this ancestral miracle play, which probably more than anything else shaped Western ideas about human freedom, it is knowledge, knowledge of good and evil, that raises man above all other creatures. The serpent's words sound as if he anticipated the M'Naghten rule, or perhaps we would come closer to the truth in assuming that the British Lords who formulated the test were somehow reminiscent of the Biblical story. This was in 1843. In 1956 there are probably a good many among our contemporaries who would hesitate to place reason so high. Yet, should there be any psychiatrists in this group of sceptics they would, when working as psychotherapists, put their faith in the healing power of insight. They are convinced that they can pass on their own knowledge of human nature to others, enlighten them, and help

- This and the preceding paper are part of a symposium held at a Grand Rounds Conference on May 16, 1956, at the University of California School of Medicine, San Francisco, arranged by the sub-department of Homeopathy and sponsored by the Homeopathic Foundation of California. The other two participants were Dr. Karl M. Bowman, Head of the Department of Psychiatry, who spoke on "Psychiatric Testing of Mental Freedom," and Mr. Thomas C. Lynch, District Attorney of the City and County of San Francisco, who spoke on "Forced to Decide."

*Veterans Administration Hospital, Lexington, Kentucky. 
them to gain insight into their past and to face their conflicts. Reason, it seems, may conquer even the demonic forces of the unconscious.

Insight into their own condition was the first knowledge imparted to Adam and Eve. Before they had tasted the forbidden fruit "they were both naked, the man and his wife, and were not ashamed." They were naked but they did not know it. With the magic meal a metamorphosis occurred. "The eyes of them both were opened, and they knew that they were naked." Man had grown beyond the limitations of his former self.

To know something means to determine the factual in relation to the potential, the particular in relation to the general, the part in relation to the whole. A knowing being is one no longer bound by actuality. To know what something is implies realizing what it could be but is not. To know the world implies knowledge of oneself. One is not without the other. The Bible tells us in a lapidary style that knowledge-scientia-is accompanied by conscientia, conscience. The fruit from the tree of knowledge bestowed upon man the power of self-reflection. He saw himself as in a mirror and was not pleased with what he saw. He discovered the discrepancy between the actual condition and a better one, between fact and ideal.

In everyday life we use the mirror for esthetic purposes. There we also compare the actual condition with a standard and "make ourselves up" to meet the requirements of the ideal. As Hamlet said to Ophelia: "God gave you one face and you make yourself another." The particular precepts of the make-up vary with times and places; the tension between fact and ideal is permanent. Physical reflection of light is, though a necessary, not the sufficient condition for the perception of a mirror image. Without selfreflection the optical reflection would give us an illusion of reality, as it does to animals. Knowing about my existence in the world I can meet the one who appears in the mirror as my own self and thereby act as my own judge. Self-reflection, which makes a comparison of fact and ideal possible, makes it also inescapable.

Traditional interpretation-well documented by the painters' and sculptors' fig leaves-relates the discovery of nakedness to sex and concupiscence. The language of the Old Testament is not 
Victorian; nakedness may mean more than sex alone; it may refer to nature, animal nature in general. Enlightened through the power of the forbidden fruit, man recognized what he had beenand still was: an animal. In knowing, he had emancipated himself from the bondage of natural existence and yet remained bound by it: he had become an animal rationale.

Ashamed and afraid, "Adam and his wife hid themselves from the presence of the Lord God." Shame is an offspring of self-reflection. We know how we are and how we ought to be. We know how we ought to be and reject what we are. We recognize a deficiency, a debt. "Ought," for good reason, is the past tense of "to owe." Self-reflection enables and forces us to see ourselves as others see us. Ashamed, we fell responsible to ourselves even before accepting another as our judge.

The Biblical drama developed fast. Man's first action immediately led to man's first trial. God summoned Adam, who answered ${ }^{1}$ from his hiding place amongst the trees of the garden; in this scene of calling and responding, "re-sponsibility" is enacted as in a charade. The call for the culprit was followed by a hearing, the hearing by the sentence. The procedure of the most supreme court put the M'Naghten rule into operation for the first time: "Hast thou eaten of the tree, whereof I commanded thee that thou shouldest not eat?" asked the Lord. Adam did not plead innocent, he did not claim not to know the nature and quality of his act. Instead, he asked for mitigation, blaming Eve, who in turn blamed the serpent. In Eve's words, "The serpent beguiled me, and I did eat," responsibility apparently comes to rest upon Satan, the great tempter. Adam's more sophisticated defense, "The woman whom thou gavest to be with me, she gave me of the tree, and I did eat," vaguely blames the Lord himself. However this may be, their behavior was not heroic, not like that of the Titans in Greek mythology and tragedy. Unlike Prometheus, they did not openly challenge God. Even so, the Lord of the garden of Eden was frightened: "Behold, the man is become as one of us, to know good and evil: and now, lest he put forth his hand, and take also of the tree of life, and eat, and live forever: Therefore the Lord God sent him forth from the garden of Eden, to till the

1 The etymological meaning of "answer" is anti-swear. 
ground from whence he was taken." Passing sentence, God cursed Adam and Eve; he cursed the serpent and the ground for Adam's sake. The expulsion from Eden, however, was not a part of the sentence; it was a preventive measure. Driving Adam from Eden, God acknowledged that man's rebellion had been successful; he blamed man for his deed, but he did not-or could not-make it undone. He did not or could not take away knowledge of good and evil. Disobedient, man had shaped and accepted his destiny; his rebellion first made him man, raised him above the level of mere animal existence. To quote the closing lines of Paradise Lost where Milton describes Adam and Eve's exodus from Eden:

Some natural tears they dropped, but wiped them soon.

The world was all before them, where to choose

Their place of rest, and Providence their guide.

They, hand in hand, with wandering steps and slow

Through Eden took their solitary way.

Man left the garden of Eden as homo sapiens.

Myths reveal lasting forms in dramatic sequence, generic structures as outcome of single events. The myth of the garden of Eden joins together knowledge with human hubris, knowledge of good and evil with self-reflection and death, insight into the discrepancy between fact and ideal with shame, guilt, and remorse; it reveals man's place in the cosmos, his relation to things above and below; it gives an account of human misery and bondage, but no less of human freedom and grandeur.

Christian theology read the story of Genesis 2 and 3 not as a myth but as the authentic report of a historical fact: of Adam's fall. His disobedience brought sin and death into the world; through him, man, now living in a state of corruption, lost his freedom. But how could he ever have been free at all? How could Adam's deed as an act of his own volition be reconciled with God's omniscience and omnipotence? Emphasizing the infinite distance separating man, the creature, from the Creator in his absolute majesty, the theologians made it difficult to understand how either man or God could will. As volition is related to change and thereby to time, God, the Immovable Mover, the Everlasting, appears above will, and man, through God's omniscience, without will. Luther and Calvin, no less than Augustine before them, 
found themselves entangled in the vexing problems of predestination.

\section{II}

You may wonder why I should devote so much time to a discussion of theological problems. They seem antiquated or, at least, of little concern to the modern scientist. Even if this were so, the reign of religious tradition did not come to a sudden end with the secularization of the problems. In a discussion of human freedom determinists as well as indeterminists, arguing the pros and cons of free will, use, even in our day, criteria borrowed from theology. They inadvertently continue a medieval controversy: the theological dispute about the supremacy of will or intellect in God. While, according to Thomas Aquinas, God created what he in his wisdom recognized as good, the theological voluntarists protested that to declare God's will dependent on God's wisdom would mean to set a limitation to his omnipotence. God, Duns Scotus taught, created the world in absolute arbitrariness. The world is good because God made it so; he did not make it so because it was good. As Luther, writing about the "servitude of human will," later said: "It is God whose will is without any cause or reason that could prescribe to it any measure or rule, for nothing is equal or superior to God's will, which is the rule of everything." In this religious philosophy God alone appears free-and absolutely free-while all others are bound by the necessity of his decree. At this point things could not and did not rest. Practice cannot work with such theories. It makes little difference whether human freedom is denied because of God's omnipotence or because of the inexorable reign of physical laws.

Kings and prices who claimed to rule by the Grace of God were the first to use divine sovereignty as a model for their own absolutism. But the common man also demanded his rights. In a democracy everyone expects his will to be respected. Not without reason do we spell " $\mathrm{I}$ " with a capital letter, and sometimes grant even to the poor Ego a majestic initial. Descartes-speaking for the common man-vindicated the freedom of human will as hardly different from divine sovereignty. $\mathrm{He}$ distinguished knowledge and the power of choice, or of free will, as two faculties. "The 
will," he said, "is much wider in its range and compass than the understanding . . . it is free will alone or liberty of choice which I find to be so great ... that it is for the most part this will that causes me to know that in some manner I bear the image and similitude of God. . . ." Descartes understood the will as an autonomous faculty, an agent acting in complete independence, capable of counteracting other powers and interfering with causality. This caricature of the concept of volition has shown a remarkable tenacity.

Theological ideas survive in present-day psychological concepts, they persist in the thinking of existentialists and psychoanalysts. When Alexander and Staub reject the concept of free will as a "postulate of the moralists that the Super-Ego does or should rule supreme and unlimited in the psychic apparatus of men,"2 the lineage of their ideas is obvious. The moralist and the psychoanalytic amoralist move on the same level. Interpreting free will as unlimited spontaneity and complete arbitrariness, they argue in the abstract, they are fighting windmills.

Indeed, if free will were synonymous with a "conscious Ego, actually [possessing] the power to do what it wishes,"* then one would have to agree with psychoanalysis, which "considers the human psychic apparatus as a system which is fully, and without a single gap, determined by psychological and biological causative factors," * provided that human behavior could be explained as the functioning of a so-called psychic apparatus steered by such strange things as drives, ideas, thoughts, and memories.

An "apparatus" certainly cannot be held responsible either for its bad or its good actions. Responsibility cannot be limited to one account only. If we are not to be charged for our shortcomings, we must not be credited for our accomplishments; fault and merit vanish together. To escape from such an intolerable situation, Alexander and Staub concede that "we may for practical purposes hold the individual responsible for his acts." The authors will allow us to "assume an attitude as if the conscious Ego actually possessed the power to do what it wishes." However, in an apparatus determined by causative factors all events are of the same kind. They occur not hypothetically nor probably but actually. Actuality is their one and only mode of occurrence.

2 Alexander \& Staub. The Criminal, the Judge, and the Public, 1931, 70 ff. 
The Apparatus named Alexander has not the power to make any assumptions. Running on one track, it cannot be so cynical as to treat some-one as free while knowing that he is not. Any fiction, whatever its content, is in itself an expression of freedom. An apparatus that cannot choose between right and wrong cannot distinguish between true and false either. It knows of no degrees of validity. In such a machine an error is just as much determined as insight. The accidental distribution of circumstances determines in an Apparatus Smith the appearance of one set of ideas, in an Apparatus Jones the appearance of another set. Neither of them is wrong and therefore neither of them is right; both simply are what they are. They do not contradict each other, just as little as rain in San Francisco contradicts sunshine in San Diego. If determinism is right, a meeting like ours today is utterly senseless. The hope of gaining knowledge would be the most deceptive of all human illusions. Indeed, we would be cursed to remain forever the captives of this or any other illusion. Yet, whether we affirm or deny human freedom, we claim to know something, we offer proofs and rules-not causes-for our convictions. The determinist, in denying the possibility of human freedom, affirms it by his very denial.

\section{III}

It may, therefore, facilitate our task to consider human freedom in its relation to knowledge. Let us analyze in full, for instance, the implications of the proposition: The earth is round. This is a rather simple statement; at least we expect every normal adult to grasp its meaning. We won't argue its truth but confine ourselves to a consideration of the connotation of the sentence, and this will give us plenty to do.

1. Some behaviorists today adhere to a semantic theory that considers words are substitutes for absent objects. An acoustical stimulus, the theory says, replaces the original one. An organism supposedly reacts to the substitute as it would to the signatum. But speaking about the earth, we do not refer to something absent. This room and this city belong to the earth.

2. The earth is not absent, but it is not present either. For the word "earth" does not signify this room or this street or state; it indicates the earth as a whole. According to the semantic theory 
just mentioned, the object-stimulus should precede the acoustical stimulus, but no-one has ever seen the earth as a whole. Even from an artificial satellite the view would always be limited to a part of the surface and certainly would not show the depth of the earth.

The word "earth" signifies an object which as such is never directly accessible to us.

3. The question therefore arises: How can we, always limited to the parts, grasp the meaning of the whole? The usual answer to such questions is: through past experience. Yet in every single one of these past experiences we found ourselves somewhere-in a room, on a street, on a hillside-always encircled by a horizon. Even if a strictly single experience could be joined, or join itself, to another, all of them put together would yield but a hodgepodge of fragments, not a whole. Generalization, another typical answer, would not provide a better explanation; it does not remove the horizon. Through generalization we would obtain a pseudo-universal, a segment of space with vague, ill-defined boundaries. Yet the astronomer has very precise ideas about the earth as a sphere. On this globe-conceived as a whole with a permanent structurehe accurately determines latitudes and longitudes, precisely calculates the length of the equator, and exactly predicts eclipses of moon and sun. Like him, the navigator finds the position of his ship on the spherical surface of the earth in its relation to sun and stars, knowing exactly the path of this our planet in relation to the orbits of other celestial bodies. Through sensory experience alone the sailor gains no answer to the question "Where?"; he is lost in his "Here," somewhere on the boundless ocean.

To understand a part as a part demands that we reach potentially beyond the visible horizon, from the known into the unknown; this in turn demands that we understand our actual experience as a phase in the continuum of experiencing. Let us suppose we inspect a large building, a house containing many rooms: we walk from room to room, we climb from floor to floor. In every moment we are confined to one small sector of the whole building; indeed, to see only one room as a whole we have to turn around to connect one view with many others. Yet at the end of our tour we know the building as a whole, though with one glance we have never actually seen it as such. Through the sequence of 
our steps in time we have become familiar with its lasting structure. When we speak about it, we eliminate the temporal order of the operation through which we gained familiarity; the man who lives in it or owns it, buys it or sells it, thinks of the building in its permanent form. While experiencing in time, we experience the flux of time itself; our experience does not consist of a sequence of impressions, but we have the impression of sequence; drifting in the flux of time we are, nevertheless, related to a timeless order.

On our trip through the building we found every given moment meaningfully related to the next one and finally to the whole structure. Familiar with the order of the whole, we definitely know where we are and how to direct the next step. Passing through the building we find ourselves as a motile partner of the environment, at any given moment confined to one position but related to many others; while we are here we are-potentiallyover there.

4. Sensory experience would never lead to the insight "the earth is a sphere." This statement is made in strict contradiction to the evidence of our senses. Far from obtaining the proposition "the earth is a sphere" through abstraction from the details of concrete experience, we abandon this primary information about our "environment" and subordinate the most obtrusive sensory data to the never directly visible frame of reference: the earth. Measured against the evidence of sensory experience our proposition is dangerously absurd; for it leads to the conclusion that the inhabitants of the Southern Hemisphere, our antipodes, hang down from the ground into the void. In order to conceive of the spherical shape of the earth we have to learn the relativity of the familiar directions: above and below. We have to emancipate ourselves from the impact of sensory experience and to deny its absolute validity. We must have the freedom to reject the claim things make upon us. We no longer comprehend the world as it appears to us but as it is in itself.

5. In order to accomplish this we have to transcend the limits of the here and now; we have to reflect upon ourselves, to see ourselves as in a mirror, to subordinate ourselves to a higher conceptual order. The statement "the earth is round" does not mention man or the speaker, but by implication it refers to him 
and his capacity for self-reflection. In making this statement we renounce our "natural" ego-centric position; we see ourselves moving and acting upon this globe.

6. In our statement not only the grammatical subject "the earth" but the predicate "is round" likewise demands our attention. It makes sense only in relation to what it excludes. It stipulates that the earth is not cubic, not a disc floating on the waters. In short, the predicate in this statement, as always, refers to other possibilities.

7. The predicate "is round" places the earth, still unknown in its size, into the well-known class of spherical objects. In theoretical comprehension the diameter of a sphere may have any magnitude, as long as the proportions (in Latin ratio, in Greek logos) are preserved. While we cannot see the spheric shape of the earth directly, we can represent it as a globe, provided that the diameter is devised so as to be extremely small compared with the natural dimension. I can comfortably carry a globe representing the earth in one hand; its size, weight, and distance do not matter if they are sufficiently remote from natural conditions. In speaking and thinking about the round earth we emancipate ourselves from natural size. We dematerialize the objects and ourselves. On a little globe I can show our position: here is San Francisco. Here we are. And I cover the spot with the tip of a finger. Still I refer to you and myself in our corporeality, size and weight.

8. The statement "the earth is round" is, as one says, abstract. It has no directly graspable substance: it is weightless. This abstractness of thought led all naturalistic philosophers from Hobbes to Freud to consider mind as pale and passive. Yet, if the idea "the earth is round" were powerless, we would not convene here today. For it was this idea that activated Columbus, enabled him to plan his trip and sustained him for months while sailing through the vast desert of the sea to a fantastic goal.

IV

1. Capable of conceiving the perennial structure of the earth in its timeless shape, Columbus could devise a plan to reach India traveling westward. To enact his plan he had to adapt a purely geometrical pattern to the vagaries of terrestrial space; the time- 
less had to be temporalized; the whole, transcending without a visible horizon the "here and now," had to be broken into parts and adapted to situations always confined by a horizon. In such a performance the whole necessarily "goes to pieces." The parts to which it is reduced are ambiguous. One can argue about which way is better or preferable.

2. A plan makes it possible to "com-prehend," in the true sense of that word, changing situations, to bring them into a meaningful context with each other, and to assign to them a place of relative importance, a value, in the realization of the whole. Its enactment brings coherence to previously incoherent segments.

3. The order of the plan binding together individual moments and hours of the day overrules the arbitrariness of the moment. Once accepted, the plan makes demands, it sets obligations. A decision to study medicine compels a student to follow a certain pattern for years to come; it prescribes for him from day to day what to do and where to go. While it says what he ought to do, it gives meaning to his existence beyond the realm of self-preservation; it opens the sphere of self-realization. In studying medicine the student becomes a physician; he accepts a general role; he creates his own social self. This possibility of conceiving an order and of performing it is not established by a castration-threatening father. The human capacity to break through the boundaries of the horizon, far from being a mere hindrance to the direct satisfaction of drives, enables him to give meaning to his life beyond the moment. In the biological circle of need and satisfaction, be it in man or animal, one transitory moment replaces the other one. But man can transcend this temporal sequence and relate his transitory action to a timeless or a permanent embracing order.

Man lives on two levels: self-preservation and self-realization. While he is able to emancipate himself from the impact of immediate sensory experience, the freedom to understand subjects him in turn to the demands of a new higher order. Human society and history make self-realization and thereby meaningful existence possible. But every order sets the rules of the game. The rules enable us to play and enjoy the game. At the same time they limit the freedom of the player; he has to follow suit. He can try to cheat, to renege; he can try to turn away from the rules in the direction of self-annihilation. But he cannot simply omit self-realiza- 
tion. Remote and immediate satisfaction, lasting order and temporal sequence, self-preservation and self-realization are in permanent conflict.

4. We want what we are in want of: Nobody could seriously wish to go where he already is. Wants and needs, wishes and desires, are related to actual situations, thereby limited by the past while open to the future. They do not act as a mere vis a tergo. They must not be construed as independent entities, as variables which determine the behavior of an apparatus. We are those who are in need, who wish and desire according to our mode of beingin-the-world.

We shall never understand the possibility of aiming at a goal if we do not consider first the conditions prevailing at the start. Obviously, we can only wish to go where we are not, strive to acquire what we have not, desire to become what we are not. But the double connotation of "wanting" expresses precisely the fact that the "want" is no mere deficiency. We are in want of something because we are at every moment in a state of transition, incomplete, capable of, but also in need of, completion. In wanting something we are directed to that which is lacking, to that which we have-not yet. When thirsty, we look for a drink; when we stretch out our hands for a glass of water, we are "longing" for it at the actual moment; but what we are longing for, the water, offers itself from a distance, as a future goal. We have to move over-there in order to reach it and incorporate it. In this act of searching we are directed to something which we see, now, in its remoteness, something with which we are-not yet-united. When we strive for a goal, the future advances into our present. Places over there within the visible horizon appear to us mobile beings as potential goals, attractive or repulsive.

Thirst and the desire to drink come with the organism's need for water. Desires are directed to the future; the term "tension reduction" has been introduced to eliminate all teleological interpretation; the concept of need, however, is also a teleological term. There are no needs in physics. In colloquial parlance we injudiciously ascribe needs to inanimate things, to utensils and artifacts no less than to living creatures. When we say the car needs lubrication or the fence needs fresh paint, we actually mean that $W E$ want the car to run smoothly, that $W E$ prefer a fence in 
good repair to one wearing away. Needs are related to preference. They occur where there is an alternative between the various conditions of an object, where one of them is preferable to us or better per se. Needed is the means of procuring a preferable situation. The statement "we are badly in need of rain" expresses both that we prefer a green lawn to a brown one and that the plants themselves in our gardens and fields will be better off after a rain. Biology recognizes optimal conditions, not established by human preference but distinguished through their relation to survival or death, fertility or sterility, health or disease, growth or waste. Plants and animals have needs in so far as among the many possible conditions there are some by nature preferable to others. While needs are always related to optimal conditions, the means of preserving or restoring them vary with the hour. After many days of sunshine rain is needed; after many days of rain, sunshine.

Plants are not organized to contribute actively to the fulfillment of their needs. Their fate is determined by soil, weather, climate; the animals, however, depend on their own activities for self-preservation. They must care for themselves; motility enables them to do so. The mighty oak rooted in the ground must wait for the clouds to bring the rain, but a little bird perched on one of its branches, free to move around, is able to search for water. Animal locomotion is related to an organization of space where the means of preservation, the "goods" of life, are unevenly distributed; it is not related to mathematical or physical but to terrestrial space; on this terrain the animal moves in zones of preference; its movements aim at a goal; they are directed to and from locations endowed with physiognomic values, to places attractive or repulsive. Animal motion, as all meaningful action, is directed to the preferable. While the human way of knowing the world and of understanding oneself opens new frontiers to man, his freedom of action is rooted in his animal nature.

There would be no legal problem of responsibility if those who may be considered as not responsible (on the human level of action) had not, nevertheless, been acting in some way (on a lower level).

5. The sentence "the earth is round" is but a puff of air, it is gone with the breath which pronounced it; yet it is valid. Its validity means that it will have the same connotation everywhere 
for everybody at any time. Thinking does not consist of single thoughts which as "causative factors" move the thinking apparatus like a coin thrust into a vending machine.

Considered as an apparatus the astronomer who measures the galaxies fills no more than a tiny volume of space. The only connection of the apparatus with the universe is through the two small pencils of light which traverse the pupils. An apparatus does not see any object over there; receivers are hit by light at the end of its travel. Photochemical processes occur in the retina-all of them but local events. While an excitation passes from the receiver to an effector, none of the parts involved reaches beyond itself. The brain which controls input and output does not know the muscles which through their contractions move the apparatus, nor is an apparatus aware of its own position or of the relation of its "here" to places "over there." Whatever happens in an apparatus is in line with physical determinism, i.e., all events are single, particular, local events determined by other events within the immediate neighborhood, the present determined by the past, and by the past only. An apparatus is limited to its proximity; there is no action at a distance, no awareness of the other as the other. An apparatus has no environment and no needs. An apparatus cannot measure, because it has no relation to the other; it cannot count, because it cannot transform the sequence of events into the idea of sequence; it cannot predict, because it has no relation to the future. But we-man and animal-reach beyond the proximity of adjacent space; we see objects at a distance, as the other; we have an environment; and as thinking beings we are in a relationship to the world which transcends the here and now. In physics spatial relations are of the order; side by side. The relationship of an experiencing being to the world is that of being opposite, namely, to the ground from which we arise, and to the things which we face from a visible distance. In moving we discover the lasting order of ground and environment where we find ourselves as a part, belonging, yet separate and opposite, aware of our own position in relation to the whole, capable of moving in the space of action to distant goals, limited to the present and yet reaching beyond the actual moment, recording the past and predicting the future. 
6. Astronomy was once considered one of the arts called liberal because they were thought worthy of a man, free in the political sense, and supposed to make him free in the moral sense to control, not to repress, his passions. To this we may add free in the technical sense to shape, if not to dominate, nature for his own ends. Science liberates man, but it is man who creates science, because he is free to transcend the confines of sensory experience. Yet while transcending them in thought he does not leave them altogether. The first move of breaking through the boundaries must be followed by a second one: the return to the "cave."

7. Thus, there are two basic forms of disturbances: the incapacity to transcend the boundaries, and the unwillingness to accept the burden of self-realization. The first, which occurs on the way out-so to speak-in psychoses and mental deficiencies, will lead the indicted into the closed ward, the second into prison. 